\title{
EMISSIONS OF SOME GREENHOUSE GASES FROM THE MANURE OF EWES FED ON POMEGRANATE PEEL, YUCCA EXTRACT, AND THYME OIL
}

\author{
YuRTSEVEN, S. ${ }^{1 *}-$ AvCI, ${ }^{2}{ }^{2}-$ ÇETIN, M. ${ }^{1}-$ ÖZTÜRK, I. ${ }^{1}-$ BOĞA, M. ${ }^{3}$ \\ ${ }^{I}$ Department of Anim. Science, Faculty of Agriculture, University of Harran \\ 63000 Şanliurfa, Turkey \\ ${ }^{2}$ Faculty of Veterinary Medicine, University of Harran, 63100 Şanliurfa, Turkey \\ ${ }^{3}$ Bor Vocational School, Ömer Halisdemir University, 51000 Niğde, Turkey \\ *Corresponding author \\ e-mail: syurtseven2001@yahoo.com; phone: +90-414-318-3474; fax: +90-414-318-3274 \\ (Received 24 $4^{\text {th }}$ Apr 2018; accepted $20^{\text {th }}$ Jun 2018)
}

\begin{abstract}
Sixteen dairy ewes 1 to 2 months pregnant and weighing $50.4 \pm 1.02 \mathrm{~kg}$ on average were randomly assigned to one of the four treatments, four animals to each treatment: 1) control, 2) yucca saponin (YE, 0.1\%), 3) pomegranate peel (PP, 15\%), or 4) thyme oil (TO, 0.1\%). Total gas production from the fresh manure was measured and the contents of $\mathrm{CH}_{4}, \mathrm{~N}_{2} \mathrm{O}$, and $\mathrm{CO}_{2}$ were determined. Digestibility in vivo and nitrogen balance were also determined. Feed intake and body weight were not affected whereas some properties of the manure (dry matter, total N, ADF, and NDF but neither ash nor $\mathrm{pH}$ ) were affected by the composition of the feed. Total manure production and the emissions of $\mathrm{CH}_{4}$ and $\mathrm{CO}_{2}$ expressed as parts per million per millilitre of manure were similar in all the four treatments whereas the content of $\mathrm{N}_{2} \mathrm{O}$ was higher in the control. Supplementing the rations with tannin, saponin, or thyme oil reduced $\mathrm{N}_{2} \mathrm{O}$ emissions from the manure.
\end{abstract}

Keywords: methane, carbon dioxide, nitrous oxide, livestock wastes, food by-products

\section{Introduction}

Livestock waste is an important source of greenhouse gases (GHG). Manure contributes directly to emissions of nitrous oxide $\left(\mathrm{N}_{2} \mathrm{O}\right)$ - which has a global warming potential 298 times that of $\mathrm{CO}_{2}$ (Mosier et al., 1998) - by stimulating nitrification and denitrification (Tang et al., 2016). Methane $\left(\mathrm{CH}_{4}\right)$ is also emitted during anaerobic fermentation of organic matter, especially during the storage of manure. The amount of GHG released from manure depends on the nitrogen $(\mathrm{N})$ and carbon $(\mathrm{C})$ content of the manure, the duration over which it is stored, the animal, and the diet. Increasing concern about mitigating the adverse effects of climate change has led to greater interest in reducing the emissions of GHG from all sources including manure from ruminants.

Pomegranate is grown on a large scale (about a million trees) in south-eastern Turkey, especially in Şanliurfa province, and its productivity has remained high over several decades (TUIK, 2014). Local production and consumption of pomegranate have greatly increased in recent years (8000 tonnes a year) which, in turn, have led to greater quantities of pomegranate peel (PP) and seeds. The peel is a waste product of processing the fruit for juice for human consumption. Pomegranate is reported to contain up to $48 \%$ peel (Zarei et al., 2011), which is rich in hydrolysable tannins and saponin. Ullah et al. (2012) estimated the crude fibre content of PP at $21 \% \pm 0.6 \%$, and Feizi et al. (2005) estimated its crude protein content at $11.4 \%$. Pomegranate peel containing tannins and saponin may improve $\mathrm{N}$ utilization efficiency and thereby 
decrease the $\mathrm{N}$ content of manure, which, in turn, may affect $\mathrm{N}_{2} \mathrm{O}$ emissions because less $\mathrm{N}$ is available to the denitrifying bacteria that use the manure as substrate. The addition of saponins from PP can thus modify the $\mathrm{C}$ and $\mathrm{N}$ contents of sheep manure.

Another recent trend has been to use the oil from aromatic plants directly instead of extracting essential oils from such plants, because extraction is difficult and not particularly efficient. Many plant essential oils stimulate rumen fermentation at high concentrations. Thyme (Thymus vulgaris) oil is an antioxidant (Seung-Joo et al., 2005) and contains about $15 \%$ essential oil (soluble in alcohol or steam). However, in vivo investigation is necessary to determine whether these oils can be used successfully to inhibit rumen methanogens with lasting effects on emissions from manure without any adverse effects on digestion.

Another possible candidate to control the production of GHG from manure is the extract of yucca, which contains two active components: a glyco component that binds ammonia and a fraction of steroidal saponins, which has the properties of a surfactant. Saponins also seem to have shown some potential in reducing enteric $\mathrm{CH}_{4}$ production (Pal et al., 2015). However, the effects of tannins from PP, thyme oil (TO), and yucca extract (YE) on the production of $\mathrm{GHG}\left(\mathrm{CH}_{4}, \mathrm{CO}_{2}\right.$, and $\left.\mathrm{N}_{2} \mathrm{O}\right)$ from manure and the overall nutritional effects of $\mathrm{PP}, \mathrm{TO}$, and $\mathrm{YE}$ are unknown-which is why the present study sought to observe the effects of PP, YE, and TO on the emissions of the above three GHG from sheep manure under routine farming practices such as open-air stool administration.

\section{Material and methods}

\section{Animals and experimental groups}

Research on animals was conducted according to institutional committee on animal use (ethical document number: KSU-2013/08-3). The experiments took place between 2 and 10 April 2014 at the Sanliurfa province in the Southeast Anatolian Region of Turkey, which lies on $37^{\circ} 9^{\prime} 32.9364$ latitude and $38^{\circ} 47^{\prime} 48.8724$ longitude. The mean air temperature was $17^{\circ} \mathrm{C}$ and the maximum was $27^{\circ} \mathrm{C}$. As a source of tannins, sundried PP was collected from pomegranate-processing plants in Şanliurfa City and ground fine enough to pass through a 3 to $5 \mathrm{~cm}$ sieve. The other source of forage was lucerne hay cut into 3 to $5 \mathrm{~cm}$ long pieces.

A total of 16 adult fat-tailed Awassi ewes 1 to 2 months pregnant, 2 to 3 years old, and weighing $50.4 \mathrm{~kg} \pm 1.02 \mathrm{~kg}$ on average were randomly assigned to one of the four treatments (4 ewes in each treatment serving as 4 replicates). Each ewe was kept in a $1.5 \mathrm{~m} \times 1.5 \mathrm{~m}$ pen. The sheep were housed in individual cages and had free access to fresh water throughout the study. They were fed separately ad libitum with a total mixed ration (TMR) containing a mixture of a concentrate and lucerne hay. The four treatments were as follows: 1-) control, (only the basal diet); 2-) YE, (the basal diet supplemented with YE at the rate of $1.5 \mathrm{~kg}$ of YE per tonne of the ratio; 3 -) PP, or $15 \%$ of ratio (that is, $150 \mathrm{~kg}$ of the mix per tonne of the ratio; or a mix of $38 \% \mathrm{PP}$ and $62 \%$ lucerne hay as forage sources, w/w); and 4-) TO, (the basal diet supplemented with TO at the rate of 1 liter per ton of the ratio). While determining the amounts to be included in the ration, PP was used as feed material and TO and YE were considered as extract. The amount of PP was designed to not exceed $20 \%$ in the direction of other studies (Shabtay et al., 2008). The amounts of TO and YE were determined based on the manufacturer's recommendation. 
The diets were so designed that all the four treatments were equal in terms of the number of calories and the amount of $\mathrm{N}$ over the duration of the experiment, and were also comparable in terms of the proportions of macronutrients and energy:proteins balance (Table 1). All rations were set to be a standard milk ration as recommended by the US National Research Council (NRC, 2007).

The experiment, including a 10 day adaptation period, lasted for 17 days. Each ewe was weighed at the beginning and at the end of the adaptation period. Feed intake was monitored over this period. Feed intake and feed refused (amount of feed left untouched) were recorded before the morning feed and weighed after one week during the adaptation period, the total feed intake being the difference between the total amounts of feed offered and refused.

Table 1. The composition of the experimental diets ( $\mathrm{g} / \mathrm{kg}$ of feed)

\begin{tabular}{|c|c|c|c|c|}
\hline & Basal diet & YE & $\mathbf{P P}$ & TO \\
\hline Barley & 10.0 & 10.0 & 10.0 & 10.0 \\
\hline Corn & 493.3 & 493.3 & 428.4 & 493.3 \\
\hline Wheat bran & 10.0 & 9.3 & 10.0 & 10.0 \\
\hline Cotton seed meal & 117.0 & 116.2 & 149.2 & 117.0 \\
\hline Lucerne hay & 357.9 & 357.9 & 237.6 & 357.7 \\
\hline Plant oil & 10.8 & 10.8 & 13.8 & 10.0 \\
\hline Vitamins-minerals supplement $^{* *}$ & 1.0 & 1.0 & 1.0 & 1.0 \\
\hline Pomegranate peel & 0.0 & 0.0 & 150 & 0.0 \\
\hline Thyme oil ${ }^{* * * *}$ & 0.0 & 0.0 & 0.0 & 1.0 \\
\hline Yucca extract & 0.0 & 1.5 & 0.0 & 0.0 \\
\hline $\mathrm{DM},[\%]$ & 89.0 & 88.8 & 89.0 & 88.9 \\
\hline $\mathrm{CP},[\%]$ & 15.6 & 15.6 & 15.5 & 15.6 \\
\hline $\mathrm{ME},[\mathrm{Mcal} / \mathrm{kg}]$ & 2.7 & 2.7 & 2.7 & 2.7 \\
\hline $\mathrm{Ca},[\%]$ & 0.5 & 0.5 & 0.4 & 0.5 \\
\hline $\mathrm{P},[\%]$ & 0.4 & 0.4 & 0.4 & 0.4 \\
\hline $\mathrm{ADF},[\%]$ & 16.6 & 16.6 & 18.1 & 16.6 \\
\hline $\mathrm{NDF},[\%]$ & 24.9 & 24.9 & 25.2 & 24.9 \\
\hline Ash, [\%] & 4.1 & 4.3 & 4.4 & 4.3 \\
\hline Condense Tannin-(CT), $[\mathrm{mg} / / \mathrm{kg}]$ & 36.9 & 36.8 & 2130.5 & 36.9 \\
\hline Saponin, $[\mathrm{mg} / \mathrm{kg}]$ & 546.3 & 558.3 & 1656.1 & 546.0 \\
\hline
\end{tabular}

*Calculation based on NRC (2007). **Each kilogram of vitamin-mineral premix provides vitamin A, $800000 \mathrm{IU}$; vitamin $\mathrm{D}_{3}, 100000 \mathrm{IU}$; vitamin E, $3000 \mathrm{mg}$; Mn, $5000 \mathrm{mg}$; Fe, 5000 mg; Cu, 1000 mg; Co, $150 \mathrm{mg}$; I, $800 \mathrm{mg}$; and Se, $150 \mathrm{mg}$. ***just oil, not extract, DM: dry matter, CP: crude protein, Me: metabolic energy, P: phosphorus, ADF: acid detergent fibre, NDF: neutral detergent fibre

\section{Sampling of manure and gases}

No bedding was used in the experiment; therefore, the manure contained nothing other than feces and urine. Samples of manure for analyzing the gases were collected after leaving the sheep one day on sheets of canvas. During the collection period, urine was not separated from feces, and total manure produced by individual animals was weighed after collecting it from the canvas sheets on which the ewe stood. The manure from each ewe was sampled three times in a day through the 3-day collection periods at 
the beginning, middle and end of the data collection period and fresh weights (kilograms per day) and $\mathrm{pH}$ were recorded immediately after collection.

To measure total gas production, specially designed glass bottles $(250 \mathrm{ml}$ each $)$ were connected to the sampling device in such a way that its neck was joined to the side of the bottle. The joints were sealed with parafilm. Representative samples of manure $(100 \mathrm{~g}$ or $150 \mathrm{~g})$ from each animal were placed in these bottles, which were stored in a dryer maintained at 35 to $40{ }^{\circ} \mathrm{C}$ for $1 \mathrm{~h}$. Total gas emitted from the feces was tried to be measured with by gas pressure. For this reason, we had left a certain volume empty $(50 \mathrm{ml})$ in bottle for measuring pressure volume dependent. The gas from the 150 grams of fecal matter placed in the bottles was determined and recalculated in proportion to the daily total feces. Total gas from the manure produced in $1 \mathrm{~h}$ was measured in grams and estimated from the barometric pressure using Equation 1 (Petrucci et al., 2010):

$$
\left[m=\frac{P V}{R T}\right]
$$

where $\mathrm{m}$ is the total gas produced $(\mathrm{g}), \mathrm{P}$ is the atmospheric pressure $(\mathrm{Pa}), \mathrm{V}$ is the volume $\left(50 \mathrm{ml}\right.$ or $\left.\mathrm{cm}^{3}\right), \mathrm{R}$ is the national gas constant value, and $\mathrm{T}$ is the temperature $\left({ }^{\circ} \mathrm{K}\right)$. However, after sampling the gases, oxygen was allowed to enter the bottles by opening them and the sampling process was repeated several times so as to represent normal conditions (open-air stool administration). The manure samples were kept in sealed bottles and the gases were sampled three times a day by drawing the gas sample through a sealed syringe: the amounts of $\mathrm{CH}_{4}, \mathrm{~N}_{2} \mathrm{O}$, and $\mathrm{CO}_{2}$ in these samples were measured later with gas chromatography. (SRI Instruments-European Greenhouse Gas Chromatograph (GC) System $\left.{ }^{\circledR}\right)$. Samples were introduced to the injection port via plastic syringes. $3 \mathrm{~m}$ Hayesep D packed column was used for $\mathrm{CO}_{2}$ and $\mathrm{CH}_{4}$ analysis and 3 m Hayesep D column was used for $\mathrm{N}_{2} \mathrm{O}$ analysis. Operating conditions for the GC were as follows: injector temperature $95{ }^{\circ} \mathrm{C}$, column temperature $85{ }^{\circ} \mathrm{C}$, and detector temperature 320 to $350{ }^{\circ} \mathrm{C}$ for $\mathrm{GC}$.

\section{Feces and feed analysis}

After drying, the manure samples were analyzed following the standard AOAC procedures (AOAC, 1998), and NDF and ADF were analyzed using an ANKOM fibre analyzer (ANKOM Technologies, Macedon, NY, USA) using the methods of Van Soest et al. (1991). The samples were dried in an oven for dry matter analysis and then ashed.

The same methods were used for feed analysis. Additionally, ground pomegranate peels was treated with a condensed tannin (CT) solution $(95 \mathrm{ml}$-butanol, $5 \mathrm{ml} \mathrm{HCl}$ (35\%), $0.05 \mathrm{~g} \mathrm{Fe}_{2} \mathrm{SO}_{4}$ ) and the amount of CT was estimated by taking the absorbance values in the spectrophotometer (Makkar et al., 1995).

\section{Apparent digestibility in vivo}

Total manure produced by each animal was collected every day at 08:30 and urine was separated from the samples of manure collected for gas measurements by filtration. As the studies were done in female sheep, it was difficult to separate stools and urine. Because the feces of the sheep were in a pelletized structure, the urine was very small and the effect of urine was very insignificant. 
The digestibility was calculated as follows: digestibility $(\%)=(\mathrm{A}-\mathrm{B}) / \mathrm{A}$, where $\mathrm{A}$ is the organic matter or $\mathrm{N}$ content of the feed (the input) and $\mathrm{B}$ is the organic matter or $\mathrm{N}$ content of the faeces (the output). The data were analysed following the completely randomized design with one-way analysis of variance using the generalized linear model (GLM) (SPSS, 2013). The only factor was the difference in the rations. The treatments means were compared using the Tukey's-b multiple range test (TMRT).

\section{Results}

Compared to the control, none of the other three treatment groups showed any significant differences $(p>0.05)$ in feed intake, change in live weight, or feed conversion ratio at the end of the trial (Table 2).

Table 2. Effect of diet on some performance parameters of Awassi ewes

\begin{tabular}{c|c|c|c|c|c|c}
\hline Parameter & Control & YE & PP & TO & SEM & P $\leq$ \\
\hline Starting weight, $[\mathrm{kg}]$ & 51.50 & 49.60 & 50.90 & 49.50 & 2.55 & 0.92 \\
Feed intake, $[\mathrm{kg} / \mathrm{day}]^{*}$ & 2.28 & 2.34 & 2.37 & 2.41 & 0.08 & 0.81 \\
LWC, [kg] & -1.00 & -0.87 & -1.75 & 0.50 & 1.68 & 0.83 \\
DLWC, [kg/day] & -0.14 & -0.12 & -0.25 & 0.07 & 0.24 & 0.83 \\
FCR & 3.36 & 2.94 & 1.95 & 8.70 & 5.00 & 0.82 \\
\hline
\end{tabular}

*Fresh weight. PP: pomegranate peel, SEM: standard error of mean, LWC: overall live weight change, DLWC: daily live weight change, FCR: feed conversion ratio

The manure, however, showed significant differences between the treatments in terms of dry matter, nitrogen, ADF, and NDF (Table 3). Especially in terms of $\mathrm{N}$ content, the three treatment groups were significantly different from the control, the PP group recording the lowest values of $\mathrm{N}$, followed by the yucca group.

Table 3. Properties of manure as affected by diet

\begin{tabular}{c|c|c|c|c|c|c}
\hline Property & Control & YE & PP & TO & SEM & P $\leq$ \\
\hline DM, [\%] & $51.1^{\mathrm{a}}$ & $58.2^{\mathrm{a}}$ & $52.8^{\mathrm{a}}$ & $70.9^{\mathrm{b}}$ & 2.56 & 0.01 \\
$\mathrm{~N},[\%]$ & $1.9^{\mathrm{c}}$ & $0.8^{\mathrm{b}}$ & $0.4^{\mathrm{a}}$ & $2.2^{\mathrm{d}}$ & 0.04 & 0.01 \\
$\mathrm{Ash},[\%]$ & 13.8 & 13.1 & 13.1 & 14.5 & 1.30 & 0.84 \\
$\mathrm{pH}$ & 8.83 & 9.2 & 8.1 & 8.9 & 0.29 & 0.28 \\
$\mathrm{ADF},[\%]$ & $46.2^{\mathrm{a}}$ & $49.9^{\mathrm{ab}}$ & $51.8^{\mathrm{ab}}$ & $54.1^{\mathrm{b}}$ & 1.28 & 0.01 \\
$\mathrm{NDF},[\%]$ & $61.2^{\mathrm{ab}}$ & $58.9^{\mathrm{ab}}$ & $55.7^{\mathrm{a}}$ & $64.1^{\mathrm{b}}$ & 1.35 & 0.01 \\
\hline \multicolumn{7}{|c|}{ Nutrient intake and output } \\
\hline E. Intake [Mcal/day] & 5.2 & 5.5 & 5.4 & 5.2 & 0.07 & 0.37 \\
N intake [g/day] & 48.0 & 51.3 & 49.5 & 46.8 & 0.79 & 0.20 \\
$\mathrm{~N}$ output g/day/manure & $23.9^{\mathrm{c}}$ & $15.8^{\mathrm{b}}$ & $5.8^{\mathrm{a}}$ & $13.9^{\mathrm{b}}$ & 1.9 & 0.01 \\
\hline \multicolumn{7}{c}{ Digestibility in vivo } \\
\hline N, [\%]
\end{tabular}

*Metabolic energy intake (Mcal/day). OM: organic matter, ADF: acid detergent fibre, NDF: neutral detergent fibre, PP: pomegranate peel, SEM: standard error of mean. Different letters in the same row show significant differences $(P \leq 0.05)$ between treatments 
Adding YE, TO, or PP to the diets reduced the $\mathrm{N}$ content of the manure compared to that from the control, pointing to the higher in vivo $\mathrm{N}$ digestibility (Table 3). In other words, $\mathrm{N}$ excretion in the manure was significantly $(\mathrm{p}<0.05)$ higher in the control. The daily average $\mathrm{N}$ excretion in the total manure was $15.8 \mathrm{~g}$ with YE, $5.8 \mathrm{~g}$ with PP, and $13.9 \mathrm{~g}$ with TO (Table 3). All the three additives improved in vivo digestibility of $\mathrm{N}$ significantly, which is consistent with the above figures. However, YE decreased the in vivo digestibility of organic matter $(\mathrm{OM})$ significantly $(\mathrm{p}<0.05 ;$ Table 3$)$. The digestibility of $\mathrm{N}$ was maximum in $\mathrm{TO}$, although the manure of ewes fed with TO was rich in $\mathrm{N}$.

Finally, neither daily gas production nor $\mathrm{CH}_{4}$ and $\mathrm{CO}_{2}$ content per milliliter varied between the four groups. Overall, YE in the diet led to greater quantities of manure and lower emissions of $\mathrm{N}_{2} \mathrm{O}$ than those in the control (Table 4).

Table 4. Gaseous emissions from manure

\begin{tabular}{c|c|c|c|c|c|c}
\hline Parameter & Control & YE & PP & TO & SEM & P $\leq$ \\
\hline Daily manure production [g] $^{*}$ & $644.6^{\mathrm{ab}}$ & $1125.0^{\mathrm{b}}$ & $765.0^{\mathrm{ab}}$ & $448.8^{\mathrm{a}}$ & 91.7 & $\mathbf{0 . 0 1}$ \\
Total gas, [g/100 g of manure per hour] & 0.7 & 0.9 & 0.5 & 0.9 & 0.2 & 0.82 \\
Daily total gas, [g] & 106.9 & 113.0 & 115.0 & 91.8 & 23.6 & 0.89 \\
$\mathrm{CH}_{4},[\mathrm{ppm} / \mathrm{ml}]^{* *}$ & 1.8 & 1.8 & 2.0 & 2.8 & 0.4 & 0.45 \\
$\mathrm{CO}_{2},[\mathrm{ppm} / \mathrm{ml}]$ & 1737.3 & 1572.9 & 3183.3 & 2342.1 & 762.7 & 0.46 \\
$\mathrm{~N}_{2} \mathrm{O},[\mathrm{ppm} / \mathrm{ml}]$ & $20.85^{\mathrm{b}}$ & $5.04^{\mathrm{a}}$ & $10.76^{\mathrm{ab}}$ & $8.86^{\mathrm{ab}}$ & 3.69 & $\mathbf{0 . 0 4}$ \\
$\mathrm{CH}_{4},[\mathrm{mg} / \mathrm{h} / \mathrm{manure}]^{* * *}$ & 0.004 & 0.008 & 0.0007 & 0.0005 & 0.00008 & 0.52 \\
$\mathrm{CO}_{2},[\mathrm{mg} / \mathrm{h} / \mathrm{manure}]$ & 1.04 & 0.98 & 1.76 & 0.93 & 0.34 & 0.84 \\
$\mathrm{~N}_{2} \mathrm{O},[\mathrm{mg} / \mathrm{h} / \mathrm{manure}]$ & $0.009^{\mathrm{b}}$ & $0.003^{\mathrm{ab}}$ & $0.001^{\mathrm{a}}$ & $0.002^{\mathrm{ab}}$ & 0.001 & $\mathbf{0 . 0 6}$ \\
\hline
\end{tabular}

*Fresh weight, **from milliliter of gas sampled through a syringe, $* * *$ daily total manure $(\mathrm{kg})$. PP: pomegranate peel; SEM: standard error of mean. Different letters in the same row show significant differences $(\mathrm{P} \leq 0.05)$ between treatments

\section{Discussion}

Manure production and feed intake are often related. Manure output usually increases as the concentration of dietary fiber increases. However, the content of dietary fiber in all the diets was broadly similar although slightly greater in YE and PP (Table 2), and the higher manure production can be generally attributed to the high ADF content of the manure (Table 3) and low digestibility of ADF in YE and PP. The increased fiber content of the manure in YE and PP was probably due to the higher fiber content of these two treatments (Table 3). Weiss and St. Pierre (2010) suggested that diets with a high concentration of by-products are usually less digestible than typical forage, and that cows often consume more dry matter when their diets are rich in the byproducts, which means that the manure output is also greater. In PP, ADF content was $51.8 \%$ and NDF content was $55.7 \%$; as a result of such high content, feed supplemented with PP increased the total manure production compared to that in the control group in the current study. High manure production by ewes fed with YE was probably due to the unknown response of sheep to YE or, more specifically, to the steroidal saponin in YE, but Li and Power (2015) found no correlation between yucca saponin and manure output. Although feed intake was not affected by the treatments $(\mathrm{p}>0.05)$, it was higher in PP and YE than that in the control and TO (Table 2). 
In the present study, greater production of manure may also have been associated with a very low rate of digestion of dry matter as a result of the increased tannin or saponin content in PP and YE (Table 3) - it is well known that ADF concentration is negatively correlated to digestibility (Niyigena et al., 2016).

Ewes in the control, YE, and PP groups lost weight towards the end of the experiment but no valid inference can be drawn in this case because the differences between the all groups were not statistically significant: perhaps sheep in all groups lost weight simply because they were older ( 2 to 3 years old). Transient diarrheal events in PP groups and in some other groups may have also caused this.

Our hypothesis was that GHG production can be lowered by additives to the feed, and our results point to greater loss of $\mathrm{N}$ from the manure of ewes in the control and TO (Table 3) and significantly decreased $\mathrm{N}_{2} \mathrm{O}$ emissions from the manure in all the three additives. We speculate that the lower emissions were due to the lower $\mathrm{N}$ content of the manure as a result of greater $\mathrm{N}$ binding and inhibition of $\mathrm{N}$ transformation.

Yucca extract decreased the digestibility of $\mathrm{OM}$ in vivo significantly $(\mathrm{p}<0.05$; Table 3). These differences between the groups seem to be related to the diet or to the effect of saponin, depending on the source (YE or PP). For example, Lu and Jorgensen (1987) reported increased digestibility of OM and cellulose in sheep fed with lucerne saponins. However, in the present experiment, PP, YE, and TO as dietary supplements increased the digestibility of $\mathrm{N}$ (Table 3) and may have been increased its availability. This resulted in lower production of $\mathrm{N}_{2} \mathrm{O}$ and lower overall emissions (Table 4). Earlier research has shown that saponin-rich feed supplements reduce the population of ciliate protozoa in vitro and in vivo (Makkar et al., 1998; Valdez et al., 1986; Cieslak et al., 2013).

A decrease in the ruminal population of protozoa may increase the flow of microbial $\mathrm{N}$ from rumen and improve $\mathrm{N}$ utilization efficiency, which was reflected in the greater digestibility of $\mathrm{N}$ and lower production of $\mathrm{N}_{2} \mathrm{O}$ (Table 3). According to Makkar et al. (1998), this may also be due to lower protein degradation with tannins or from ammonia binding of Yucca schidigera. The digestibility of $\mathrm{N}$ was also higher in TO, although the manure too was richer in $\mathrm{N}$, probably because of decreased total manure production in this group.

None of the additives (PP, YE, or TO) had any impact on total gas production or on the production of $\mathrm{CH}_{4}$ or $\mathrm{CO}_{2}$, but all the three had an impact on manure production, $\mathrm{DM}, \mathrm{ADF}, \mathrm{NDF}$, and $\mathrm{pH}$ when compared with the control group (Tables 3 and 4). After defecation, the emissions are dominated by $\mathrm{N}_{2} \mathrm{O}$ and $\mathrm{CO}_{2}$, probably because of the oxygenated environment. Wulf et al. (2002) suggest that after field application of organic manure, GHG emissions are dominated by $\mathrm{N}_{2} \mathrm{O}$ and $\mathrm{NH}_{3}$, and $\mathrm{CH}_{4}$ is only of minor importance. On the other hand, when manure is stored, $\mathrm{CH}_{4}$ emissions may be considerably greater because $\mathrm{OM}$ is degraded to $\mathrm{CH}_{4}$ during anaerobic fermentation. The present experiment offered no anaerobic environment, and the oxygen-rich environment under which the manure was stored in the present study showed that emissions of $\mathrm{CH}_{4}$ and of $\mathrm{CO}_{2}$ from manure may be independent of the rumen environment and that the methane-producing bacteria may be inhibited by the oxygenrich environment. Johnson et al. (2000) suggested that $\mathrm{CH}_{4}$ emissions from the excreta of grazing cattle amount to only $1 \%$ of the $\mathrm{CH}_{4}$ emissions from anaerobic conditions. Therefore, in ruminant production systems, $\mathrm{CH}_{4}$ emissions from excreta are often ignored. Emissions of $\mathrm{CO}_{2}$ from manure depend on storage conditions and were the highest from the mouldy manure towards the later stages of the present experiment. 
Although only a few studies have been conducted so far on $\mathrm{CH}_{4}$ emissions from manure outdoors, our results reinforce the view that such manure is not a major source of methane and poses no risk to the environment.

Emissions of nitrogenous gases have also been linked to the $\mathrm{pH}$ of the manure. For example, Zaman et al. (2009) suggested that an increase in $\mathrm{pH}$ and $\mathrm{NH}_{4}$ concentration could trigger $\mathrm{NH}_{3}$ emissions during storage and after field application. Our results show a strong influence of PP on $\mathrm{N}_{2} \mathrm{O}$ emissions: the lowest emissions of $\mathrm{N}_{2} \mathrm{O}$ were seen in that treatment. The lower emissions from PP and YE were probably due to the lower contents of mineral $\mathrm{N}$ in the manure (Table 4). The concentration of steroidal saponins was $4.4 \%$ in YE (Wina et al., 2005). Generally, saponins have been found to have no effect on dry matter consumption (Valdez et al., 1986). However, saponins in YE effectively suppressed ruminal protozoa by interacting with cholesterol in the cell membrane (Wina et al., 2005). A decrease in protozoa may have increased the rate of fermentation of high-forage diets by increasing the populations of bacteria and fungi in the rumen. In ruminants, YE is believed to decrease ammonia in the rumen (Sheng Sun et al., 2017), and a reduction in rumen protozoa may have a positive effect, including $\mathrm{N}$ conservation, by altering the rumen flora in favour of bacteria and fungi. Makkar et al. (1999) also demonstrated such conservation of $\mathrm{N}$ in the rumen. These mechanisms may have contributed to the difference in the $\mathrm{N}$ content of the manure between $\mathrm{YE}$ and the control and the lower $\mathrm{N}_{2} \mathrm{O}$ emissions in YE. The higher $\mathrm{N}_{2} \mathrm{O}$ emissions from the control were probably due to the higher output of mineral $\mathrm{N}$ (Table 3). Conversely, the high $\mathrm{N}$ content but low emissions from TO may be due to the higher concentration of oil in that ration, leading to the $\mathrm{N}$ being fixed and thus less amenable to digestion. The lower moisture content of the manure in the TO group may also be responsible for the lower emissions of $\mathrm{N}_{2} \mathrm{O}$ from that group (Table 3).

Although tannin levels had no effect on the emissions of $\mathrm{CH}_{4}$ from the manure, PP, which is rich in tannins, decreased the amount of $\mathrm{N}$ lost through emissions compared to that in the control. Nauman et al. (2017) suggest that moderate levels of condensed tannins in the rumen protect dietary proteins from degradation by microorganisms, thereby increasing protein flow through the intestines.

The contents of crude protein and the amount of ammonia released from manure are interrelated. However, tannins have been shown to make plant proteins less degradable by binding with them (Nauman et al., 2017). It is well known that PP contains large amounts of tannin; these tannins, by binding to the proteins, slow down proteolysis and thus the degradation of proteins (Garipoğlu and Uçar, 2015). Fayed et al. (2012) reported similar observations for PP and found that rabbit feed that contained PP was low in digestible nutrients (crude protein and ether extract) than that without PP. The present study shows that additives such as PP and YE are an effective component of the strategy for reducing $\mathrm{N}_{2} \mathrm{O}$ emissions from ruminants given protein-rich diets (as starter diets and diets aimed at faster growth).

Under experimental conditions, cases of diarrhea were considerably fewer in ewes fed with PP than those in the other groups. In rats suffering from diarrhea, feeding with extracts of pomegranate seeds reduced fluid accumulation in the intestines by decreasing the quantity of faeces and gastrointestinal motility (Aghsaghali et al., 2011), both of which may have contributed to lowering $\mathrm{N}_{2} \mathrm{O}$ emissions. However, on the basis of daily manure production, $\mathrm{N}_{2} \mathrm{O}$ emissions per animal were lower in all the three groups compared to those in the control group. In the current study, gas production was expressed as parts per million (in milligrams) of total faecal matter (manure) per hour. 
The production was then apportioned into that of specific gases $\left(\mathrm{CH}_{4}, \mathrm{CO}_{2}\right.$, and $\left.\mathrm{N}_{2} \mathrm{O}\right)$ and expressed in the same units but per animal. Both daily manure output and total gas production increased, especially in YE, but the production of nitrogenous gases also decreased markedly in YE $(\mathrm{p}<0.05)$. The other two additives (PP and TO) also had significant effects on $\mathrm{N}_{2} \mathrm{O}$ emissions but the control group did not (Fig. 1), and neither YE nor TO had any effect on daily emissions of $\mathrm{CO}_{2}$ and $\mathrm{CH}_{4}$ (Table 4).
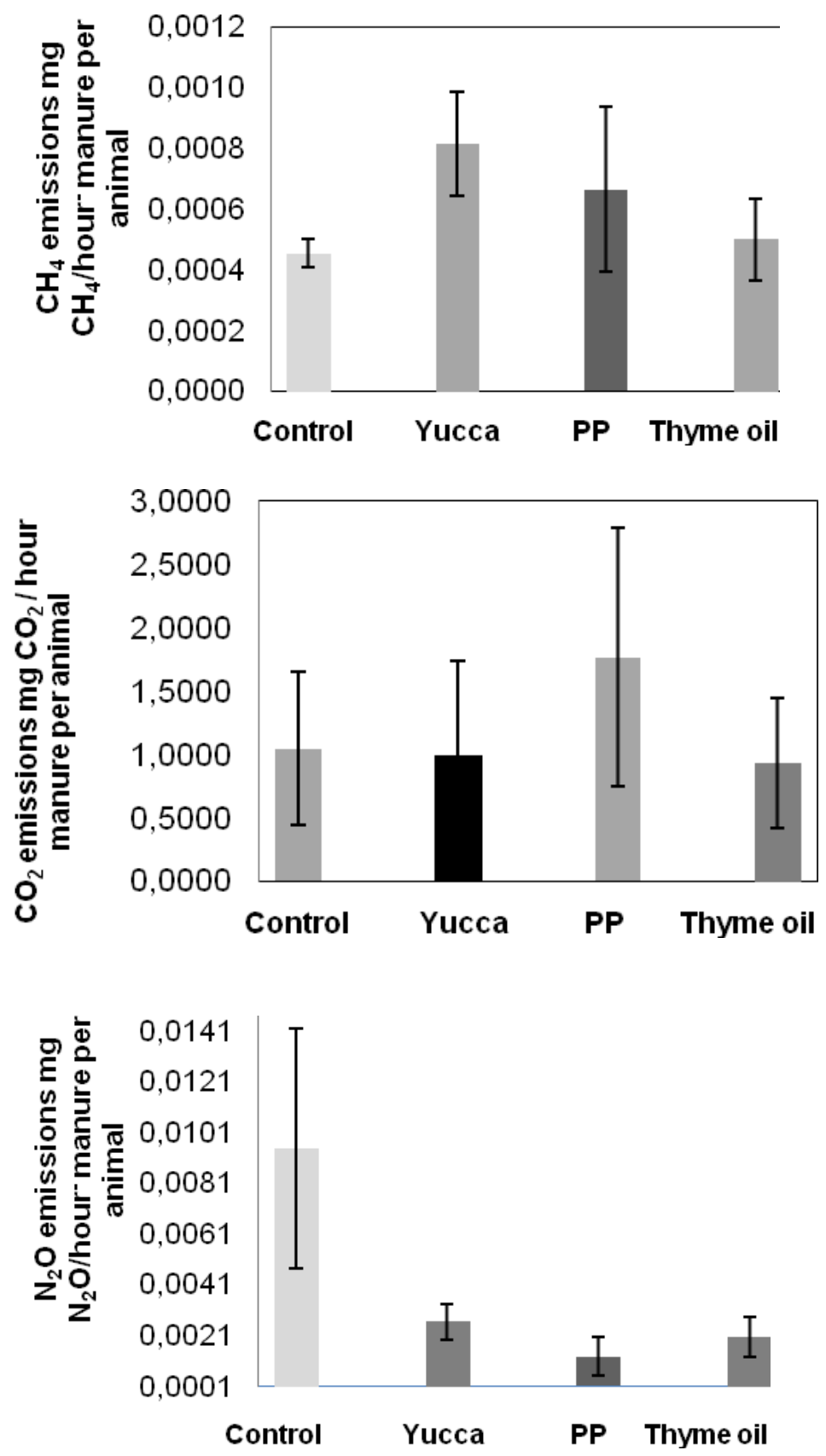

Figure 1. Emissions of greenhouse gases from manure per hour as affected by diet. The four groups did not differ significantly in terms of $\mathrm{CH}_{4}$ and $\mathrm{CO}_{2}$ emissions but differed relatively in terms of $\mathrm{N}_{2} \mathrm{O}$ emissions 
Thus, some by-products of the food industry have a potential as animal feedstuff that can reduce $\mathrm{N}_{2} \mathrm{O}$ emissions. Reducing the emissions of GHG from ruminants can put such by-products to better use and help in mitigating the adverse impacts of climate change at the same time. On the other hand, PP is widely used in folk medicine for the treatment of a variety of diseases including diarrhoea, and no metabolic disorders were observed in ewes when hay was mixed with 15\% PP (Table 1). Therefore, lucerne hay can be safely mixed with $15 \%$ dried PP; the effect of increasing this proportion should be assessed through further experiments. We advise that the feces produced in farm should be urgently evaluated as biogas or fertilizer. Otherwise it would be an important source of $\mathrm{N}_{2} \mathrm{O}$ and $\mathrm{CO}_{2}$ gases particularly but not $\mathrm{CH}_{4}$ due to the oxygenated conditions.

\section{Conclusion}

We found that the use of CT-containing PP as 38\% of the Lucerne hay as roughage feed was a good choice for sheep production. Supplementing the rations with tannin, saponin, or thyme oil reduced $\mathrm{N}_{2} \mathrm{O}$ emissions from the manure. PP, YE or TO were good choices to reduce fecal emission of nitrogen-based gases. But they did not effectively reduce the production of enteric $\mathrm{CH}_{4}$ in the rumen and energy loss through $\mathrm{CH}_{4}$ for the Lucerne hay-based.

Acknowledgements. This work was supported by the Harran University Research Committee [HUBAK] under Grant [Project no. 14039]. The Institutional Ethics Committee of KSU University (KSUZIRHADYEK-2013/08-3) reviewed and approved our application to conduct the above-mentioned experimental trial in the Dept. of Animal Science with ourselves as principal investigators.

\section{REFERENCES}

[1] Aghsaghali, A. M., Sis, N. M., Mansouri, H., Razeghi, M. E., Aghazadeh, A. M., Cheraghi, H., Golshani, A. A. (2011): Evaluating potential nutritive value of pomegranate processing by-products for ruminants using in vitro gas production technique. - Journal of Agricultural and Biological Science 6(6): 45-51.

[2] AOAC, Association of Official Analytical Chemists (1998): Official Methods of Analysis. - 16th ed. 4th rev. ed. Washington, DC, USA.

[3] Cieslak, A., Szumacher-Strabel, M., Stochmal, A., Oleszek, W. (2013): Plant components with specific activities against rumen methanogens. - Animal 7: 253-265.

[4] Fayed, A., M, Azoz, A., Zedan, A. H., Basyony, M. (2012): Effects of pomegranate peel as antioxidant supplementation on digestibility, blood biochemical and rabbit semen quality. - Egyptian Journal of Nutrition and Feeds 15(2): 343-354.

[5] Feizi, R., Ghodrat, N. A., Zahedifar, M., Danesh, M., Raisianzade, M. (2005): The influence of urea treatment on in vitro gas production of pomegranate peel. - EAAP $-56^{\text {th }}$ Annual Meeting of the European Association for Animal Production. 5-8 June 2005, Upsala Sweden.

[6] Garipoğlu, A. V., Uçar, C. (2015): Effect of tanniferous plants on proteolysis in silages. Proceedings of 9th National Zootechni Scientific Congress; Sep 3-5. Konya, Turkey.

[7] Johnson, D. E., Johnson, K. A., Ward, G. M., Brain, M. E. (2000): Ruminants and Other Animals - In: Khalil, M. A. K. (eds.) Atmospheric Methane: Its Role the Atmospheric Environment. Springer-Verlag, Berlin, Germany, pp. 112-133.

[8] Li, W., Powers, W. (2015): Effects of saponin extracts on air emissions from steers. Journal of Animal Science 90(11): 4001-13. 
[9] Lu, C. D., Jorgensen, N. A. (1987): Alfalfa saponins affect site and extent of nutrient digestion in ruminants. - Journal of Nutrition 117(5): 919-927.

[10] Makkar, H. P. S., Blummel, M., Becker, K. (1995): Formation of complexes between polyvinylpolypyrrolidone or polyethylene glycols and tannins and their implication in gas production and true digestibility in vitro techniques. - British Journal of Nutrition 73(6): 897-913.

[11] Makkar, H. P. S., Sen, S., Blummel, M., Becker, K. (1998): Effects of fractions containing saponins from Yucca schidigera, Quillaja aponaria, and Acacia auriculoformis on rumen fermentation. - Journal of Agricultural and Food Chemistry 46(10): 4324-4328.

[12] Makkar, H. P. S., Aregheore, E. M., Becker, K. (1999): Effects of saponins and plant extracts containing saponins on the recovery of ammonia during urea ammoniation of wheat straw and fermentation kinetics of the treated straw. - Journal of Agricultural Science 132: 313-321.

[13] Mosier, A., Kroeze, C., Nevison, O., Oenema, S., Seitzinger, O., Cleemput, V. (1998): Closing the global $\mathrm{N}_{2} \mathrm{O}$ budget: Nitrous oxide emissions through the agricultural nitrogen cycle. - Nutrient Cycling in Agroecosystems 52(2): 225-248.

[14] Naumann, H. D., Tedeschi, L. O., Zeller, W. E., Huntley, N. F. (2017): The role of condensed tannins in ruminant animal production: advances, limitations and future directions. - Revista Brasileira de Zootecnia 46(12): 929-949.

[15] Niyigena, V., Coffey, K. P., Coblentz, W. K., Young, A. N., Philipp, D., Bartimus, H. L., Rhein, R. T. (2016): Correlation of fermentation characteristics with intake and digestibility of alfalfa silage in gestating ewes. - Journal of Animal Science 94(5): 298298.

[16] NRC, National Research Council (2007): Nutrient Requirements of Small Ruminants. National Academy Press, Washington DC, USA.

[17] Pal, K., Patra, A. K., Sahoo, A., Kumawat, P. K. (2015): Evaluation of several tropical tree leaves for methane production potential, degradability and rumen fermentation in vitro. - Livestock Science 180: 98-105.

[18] Petrucci, R. H., Herring, G., Madura, J., Bissonnette, C. (2010): General Chemistry. Principles and Modern Apllications with Mastering Chemistry. 10th ed. - Pearson, Canada.

[19] Seung-Joo, L., Katumi, U., Takayuki, S., Kwang-Geun, L. (2005): Identification of volatile components in basil (Ocimum basilicum L.) and Thyme leaves (Thymus vulgaris L.) and their antioxidant properties. - Food Chemistry 91(1): 131-137.

[20] Shabtay, A., Eitam, H., Tadmor, Y., Orlov, A., Meir, A., Weinberg, P., Weinberg, Z. G., Chen, Y., Brosh, A., Izhaki, I., Kerem, Z. (2008): Nutritive and antioxidative potential of fresh and stored pomegranate industrial byproduct as a novel beef cattle feed. - Journal of Agricultural and Food Chemistry 56: 10063-10070.

[21] Sheng Sun, D., Jin, X., Shi, B., Xu, B., Yan, S. (2017): Effects of Yucca schidigera on gas mitigation in livestock production: A review. - Brazilian Archives of Biology and Technology 60: 1-15.

[22] SPSS, Statistical Package of Social Sciences (2013): Base 22.0. - Spss Inc., Chicago USA.

[23] Tang, J., Liang, S., Li, Z., Zhang, H., Wang, S., Zhang, N. (2016): Emission laws and influence factors of greenhouse gases in saline-alkali paddy fields. - Sustainability $8(2)$ : $2-14$.

[24] TUIK (2014): Turkish Statistical Institute. Crop Production Statistics Ministry of Development. - Specialized Commission Report, Ankara (in Turkish).

[25] Ullah, N, Ali, J, Ali Khan, F, Khurram, M, Hussain, A, Inayat-ur-Rahman, Zia-urRahman, Shafqatullah. (2012): Proximate composition, minerals content, antibacterial and antifungal activity evaluation of pomegranate (Punica granatum L.) peels powder. Middle-East Journal of Scientific Research 11(3): 396-401. 
[26] Valdez, F. R, Bush, L. J, Goetsch, A. L, Owens, F. N. (1986): Effect of steroidal sapogenins on ruminal fermentation and on production of lactating dairy cows. - Journal of Dairy Science 69(6): 1568-1575.

[27] Van Soest, P. J, Robertson, J. B, Lewis, B. A. (1991): Methods for dietary fiber, neutral detergent fiber and nonstarch polysaccharides in relation to animal nutrition. - Journal of Dairy Science 74(10): 3583-97.

[28] Weis, W. P., St Pierre, N. (2010): Feeding strategies to decrease slurry output of dairy cows. WCDS. - Advanced Dairy Science and Technology 22: 229-237.

[29] Wina, E., Muetzel, S., Becker, K. (2005): The impact of saponins or saponin-containing plant materials on ruminant production A review. - Journal of Agricultural Food Chemistry 53(21): 8093-8105.

[30] Wulf, S., Maeting, M., Clemens, J. (2002): Effect of application technique on the emission of trace gases $\left(\mathrm{NH}_{3}, \mathrm{~N}_{2} \mathrm{O}, \mathrm{CH}_{4}\right)$ after spreading co fermented slurry on arable and grassland Part 2. GHG emissions. - Journal of Environmental Quality 31(6): 17951801.

[31] Zaman, M., Saggar, S., Blennerhassett, J. D., Signh, J. (2009): Effect of urease and nitrification inhibitors on $\mathrm{N}$ transformation, gaseous emissions of ammonia and nitrous oxide, pasture yield and $\mathrm{N}$ uptake in grazed pasture system. - Soil Biology and Biochemistry 41(6): 1270-1280.

[32] Zarei, M., Azizi, M., Zeinolabedin, B. S. (2011): Evaluation of physicochemical characteristics of pomegranate (Punica granatum L.) fruit during ripening. - Fruits 66(2): 121-129. 